www.jmscr.igmpublication.org

Index Copernicus Value: 79.54

ISSN (e)-2347-176x ISSN (p) 2455-0450

crossrefDOI: https://dx.doi.org/10.18535/jmscr/v7i1.184

$\underline{\text { Research Article }}$

\title{
A study to find out the relationship between HsCRP values and complications in patients with acute coronary syndrome
}

\author{
Authors \\ Dr Saurabh Singh Tomar ${ }^{1}$ (M.D. General Medicine) \\ Dr Manisha Chauhan ${ }^{2 *}$ (M.S. Obstetrics \& Gynaecology) \\ *Corresponding Author \\ Dr Manisha Chauhan (M.S. Obstetrics \& Gynaecology)
}

\begin{abstract}
Introduction: CRP (as measured by high sensitivity assay (HsCRP) is the inflammatory marker of choice, as it has more stability, assay precision, accuracy and availability. ${ }^{3}$.

Objective: The present study was designed to evaluate- The relationship between HsCRP values and complications in patients with acute coronary.

Methodology

Study Design: Case Control Observational Study.

Study Duration: 20 July 2017 to 20 March 2018.

Results: The most common complication seen was arrthymias and it was observed that increase in HsCRP values went hand in hand with increase in number of complications.

Conclusion: More the value of HsCRP, more the complications, but with low and average risk, nil or less complications.
\end{abstract}

\section{Introduction}

By 2020 it is predicted that CVD will claim 25 million lives annually and that coronary heart disease will surpass infectious disease as the world's number one cause of death and disability ${ }^{1}$. In India, prevalence of ischemic heart disease among adults was estimated at about 96.7 per 1000 population in the urban and 27.1 per 1000 population in rural areas ${ }^{2}$.

According to the centre for disease control and prevention and American Heart Association (CDC/AHA) guidelines 2002,CRP (as measured by high sensitivity assay (HsCRP) is the inflammatory marker of choice, as it has more stability, assay precision, accuracy and availability ${ }^{3}$.
In healthy persons normal range of HsCRP is about $0.1 \mathrm{mg} / \mathrm{dl}$.

\section{Aims and Objectives}

To find out the relationship between HsCRP values and complications in patients with acute coronary.

\section{Methodology:}

Study Design: Case Control Observational Study. Study Duration: 20 July 2017 to 20 March 2018. Those patients who were having either one or more of the above mentioned exclusion criteria, were excluded from the study and out of these remaining cases of acute coronary syndrome, 35 
cases who were having acute myocardial infarction were included in Group A.

35 cases who had unstable angina were included Group B.

30 healthy age and sex matched controls were included in Group C.

\section{Inclusion Criteria}

Patients of acute coronary syndrome, (presenting within 6 hours of onset of symptoms), admitted to intensive cardiac care unit (I.C.C.U) from emergency and O.P.D of Department of Medicine, in tertiary care teaching institute of North India (F.H. Medical College, Agra)

Patients with Myocardial infarction were diagnosed based on WHO (2000) criteria, (atleast two criteria must be present) :

1. Typical (ischemic) symptoms of prolonged (>20 minutes) chest pain

2. Serial ECG changes

a) Progression from no $Q$ wave to a definite $Q$ wave

b) A Q wave progression combined with progressive ST- segment depression, developing ST-segment elevation, or progressive $\mathrm{T}$-wave inversion.

c) Persistent ST-segment elevation with progressive $\mathrm{T}$-waveinversion in sequential ECGs

d) Rise and fall of serum cardiac enzyme levels (Creatine kinase-MB, Troponin) twice the limit of normal (with reference to the upper limit of normal values).

\section{Unstable Angina}

Defined as angina pectoris (or equivalent type of ischemic discomfort) with atleast one of the three features:

1) Occurring at rest (or minimal exertion) and usually lasting for $>20$ minutes (if not interrupted by nitroglycerin administration);

2) Being severe and described as frank pain, and of new onset (i.e within 1 month) and;

3) Occurring with a crescendo pattern (i.e more severe, prolonged or frequent than previously)

\section{Exclusion Criteria}

1) Stable angina

2) Recent surgical intervention

3) Collagen vascular diseases

4) Rheumatoid arthritis

5) Patients on drugs e.g. NSAIDS, statins therapy

6) Subjects who had liver disorders, hepatitis, inflammatory disorders or malignancy

Those patients who were having either one or more of the above mentioned exclusion criteria, were excluded from the study and out of these remaining cases of acute coronary syndrome, 35 cases who were having acute myocardial infarction were included in Group A and 35 cases who had unstable angina were included Group B. 30 healthy age and sex matched controls were included in Group C.

All study patients were subjected to detailed history, thorough clinical examination and investigations like ECG, cardiac enzymes, lipid profile, echocardiography, and HsCRP to establish the diagnosis of either unstable angina or myocardial infarction.

\section{Data collection \& Statistical analysis}

The data regarding history, clinical examination, routine and special investigations of all three groups $\mathrm{A}, \mathrm{B}$ and $\mathrm{C}$ were entered in the pretested proforma and the observations were tabulated.

Statistical software namely SPSS 17.0 was used for the analysis of the data and Microsoft Word and Excel have been used to generate tables and descriptive statistics.

Logistic regression technique:

Logistic regression equation between HsCRP and Complications

$\mathrm{y}=\mathrm{a}+\mathrm{bx}$

$\mathrm{x}$ is independent variable and $\mathrm{y}$ is dependant variable 
$\mathrm{x}=$ Complication

$\mathrm{y}=\mathrm{HsCRP}$

SPSS software used to determine $a$ \& $b$ constants for logistic regression technique.

SPSS software used to determine $a$ \& $b$ constants for logistic regression technique $\mathrm{y}=4.795-2.367 \mathrm{x}$

By logistic regression technique it was observed that increase in HsCRP value had linear relationship with increase in complication.
As per AHA/CDC Scientific ststement on markers of inflammation and cardiovascular disease. Circulation 2003; 107;499.511

HsCRP level and risk of CVD were classified-

\begin{tabular}{|l|c|}
\hline HsCRP Level(mg/dl) & Risk of CVD \\
\hline$<0.1$ & Low \\
\hline $0.1-0.3$ & Average \\
\hline$>0.3$ & High \\
\hline
\end{tabular}

(CVD-Cardiovascular disease)

\section{Observation \& Results}

Table-1 Complications of cases of the present study (Group A \& Group B).

\begin{tabular}{|l|c|c|c|}
\hline S.No. & Complications & No.of cases $\mathrm{n}=70$ & Percent \\
\hline 1 & Arrhythmias & 24 & 34.28 \\
\hline 2 & Left ventricular failure. & 14 & 20 \\
\hline 3 & Post MI Angina & 5 & 7.14 \\
\hline 4 & Cardiogenic Shock & 4 & 5.71 \\
\hline \multicolumn{2}{|r|}{ Total No.of cases(GroupA+B) } & 70 & 100 \\
\hline
\end{tabular}

Comment: The most common complication seen was arrthymias in 24(34.28\%) patients followed Angina in five (7.14\%) and cardiogenic shock in by Left ventricular failure in 14 (20\%), Post MI

Table-2 Complication-wise Distribution of Cases of Group A \& B in Various HsCRP Risk Categories

\begin{tabular}{|l|c|c|c|c|c|c|}
\hline \multirow{2}{*}{$\begin{array}{l}\text { HsCRP } \\
(\mathrm{mg} / \mathrm{dl})\end{array}$} & \multicolumn{2}{|c|}{$\begin{array}{c}\text { With } \\
\text { Complications }\end{array}$} & \multicolumn{2}{c|}{$\begin{array}{c}\text { Without } \\
\text { Complications }\end{array}$} & \multicolumn{2}{c|}{ Total } \\
\cline { 2 - 7 } & No.of cases & Percent & No.of cases & Percent & No.of cases & Percent \\
\hline $\begin{array}{l}\text { LOW RISK } \\
(<0.1 \mathrm{mg} / \mathrm{dl})\end{array}$ & 0 & 0 & 8 & 11.43 & 8 & 11.43 \\
\hline $\begin{array}{l}\text { AVG RISK } \\
(0.1-0.3 \mathrm{mg} / \mathrm{dl})\end{array}$ & 3 & 4.28 & 8 & 11.42 & 11 & 15.71 \\
\hline $\begin{array}{l}\text { HIGH RISK } \\
(>0.3 \mathrm{mg} / \mathrm{dl})\end{array}$ & 34 & 48.57 & 17 & 24.29 & 51 & 72.86 \\
\hline TOTAL & 37 & 52.85 & 33 & 47.14 & 70 & 100 \\
\hline
\end{tabular}

\section{Comments}

Out of total $70(100 \%)$ cases of Group A \& B combined, 37 (52.85\%) had complications and 33 (47.14\%) uncomplicated. Out of $37(52.85 \%)$ cases with complications, 34 (48.57\%) had high risk HsCRP $(>0.3 \mathrm{mg} / \mathrm{dl})$ while remaining three (4.28\%) cases had average risk HsCRP (0.1$0.3 \mathrm{mg} / \mathrm{dl}$ ) and none had low risk HsCRP

Out of $70(100 \%)$ patients of study group, eight $(11.43 \%)$ cases had low risk $\operatorname{HsCRP}(<0.1 \mathrm{mg} / \mathrm{dl})$ and no complications, $11(15.71 \%)$ patients had average risk HsCRP $(0.1-0.3 \mathrm{mg} / \mathrm{dl})$ and only three $(4.28 \%)$ had complications and 51 $(72.86 \%)$ patients had high risk HsCRP
$(>0.3 \mathrm{mg} / \mathrm{dl})$ and among them $34(48.57 \%)$ had complications.

\section{Discussion}

The present study comprised of 35 cases of acute myocardial infarction, 35 cases of unstable angina and 30 controls.

In the similar way Honarmand $\mathrm{H}$ et al $(2011)^{4}$ studied 100 patients of myocardial infarction and 100 controls.

After application of logistic regression technique it was observed that increase in HsCRP values went hand in hand with increase in nunber of complications and indicate the prognostic 
significance of HsCRP value ( $\mathrm{p}$ value < 0.05 ).

Similar observations were obtained by C.K Mishra et al (2005) who stated that elevated HsCRP early after acute MI ( $<6$ hours) signifies underlying increased inflammation and hence, more extensive damage and complication. Hence elevated HsCRP prognosticates poor LV function and in-hospital adverse cardiac outcome in ACS. ${ }^{5}$

\section{Conclusion}

More the value of HsCRP, more the complications, but with low and average risk, nil or less complications.

\section{Funding: None}

Conflict of interest: No conflict of interest.

\section{Bibliography}

1. Zipes, Libby, Bonow, Braunwald; Braunwalds Heart Disease. A textbook of cardiovascular Medicine, 7th edition, Philadelphia, Pennsylvania; Elsevier Saunders Publishers, 2005.108 .

2. K. Park. Epidemiology of chronic non communicable diseases and conditions. In:Park's Textbook of Preventive and Social Medicine. 20th ed. Jabalpur: M/S Banarasidas Bhanot Publishers .2009:315-345.

3. Shishehmbor $\mathrm{M} \mathrm{H}$ et al. Using C-reactive protein to assess cardiovascular disease risk. Clev Clin J Med, 2003; 70(7):634640.

4. Honarmand H, Mirzajani E, RahbarTaromsari M, Saadat $F$ et al. The relationship and diagnostic value of CRP and HsCRP for myocardial infarction, African Journal of Microbiology, 2011; 5 : 3215-3219.

5. Mishra C K, Mishra A, Routray S N etal High sensitive CRP :A Prognostic marker in Acute Coranary Syndrome. Indian Heart J 2005;57:383. 